DOI: $10.2478 / \mathrm{v} 10014-012-0011-6$

Agrovoc descriptors: zea mays, maize, cereals, land varieties, crop yield, yields, seed, proximate composition, proteins, oils, starch, genotypes, phenotypes, agronomic characters, quality, plant breeding, genetic variation, biological differences, varieties

Agris category code: f01, f30

\title{
Genetic diversity and correlation estimates for grain yield and quality traits in Kosovo local maize (Zea mays L.) populations
}

\author{
Sali ALIU ${ }^{1}$, Imer RUSINOVCI ${ }^{2}$, Shukri FETAHU ${ }^{3}$, and EMILIJA SIMEONOVSKA ${ }^{4}$
}

Received May 7, 2012; accepted July 18, 2012.

Delo je prispelo 7. maja 2012, sprejeto 18. julija 2012.

\begin{abstract}
The aim of the presented investigation was to estimate the genetic diversity, and correlation analysis among yield and quality traits in twenty local maize populations. The experiment was based on randomized complete block design (RCBD) with three replications. In the study we compared grain yield, and quality traits such as protein, oil and starch content in grain. The results showed that there were significant differences among populations. The overall mean grain yield was $79.33 \mathrm{~g} \mathrm{plant}^{-1}$ with the highest grain yield in population GBK-7 (105.13 g plant $\left.{ }^{-1}\right)$. The protein and oil contents ranged between 11.02 to $13.02 \%$ and 2.56 to $5.57 \%$, respectively. The starch content varied from 68.58 to $70.92 \%$. The first two canonical discriminant functions were significant at $p<0.01$. It is important to point out the great relevance of the first two discriminant functions justifying $95.80 \%$ of the variability among populations. There were also big differences regarding phenotypic correlations. The study suggests that the quality traits are phenotypically and genotypically highly variable and therefore very useful for breeding process
\end{abstract}

Key words: local maize populations, protein, oil, starch

\section{IZVLEČEK}

\section{GENETSKA RAZNOLIKOST IN KORELACIJE MED PRIDELKOM ZRNJA IN KAKOVOSTNIMI \\ LASTNOSTMI ZRNJA LOKALNIH POPULACIJ KORUZE (Zea mays L.) NA KOSOVEM}

Namen raziskave je bil proučiti genetsko raznolikost in korelacije med pridelkom in nekaterimi kakovostnimi lastnostmi zrnja (vsebnost beljakovin, olja, škroba in pepela v zrnju) 20 lokalnih populacij koruze na Kosovem. Poskus je bil postavljen po metodi naključnih blokov v 3 ponovitvah. Za vse lastnosti so ugotovljene statistično značilne razlike med proučevanimi populacijami. Povprečni pridelek zrnja vseh populacij je znašal 79,33 g rastlino ${ }^{-1}$, najvišji pridelek je imela populacije GBK-7 $\left(105,13 \mathrm{~g}^{\text {rastlino }}{ }^{-1}\right)$. Vsebnost beljakovin se je gibala med 11,02 in $13,02 \%$, olja med 2,56 in $5,57 \%$ in škroba med 68,58 in $70.92 \%$. Z diskriminantno analizo je ugotovljeno, da sta prvi dve komponenti pojasnili 95,80\% varabilnosti med populacijami. Med nekaterimi lastnostmi so za proučevane populacije ugotovili signifikantne korelacije. Glede na veliko genetsko variabilnost smatramo, da bi proučevane lokalne populacije lahko bile koristne $\mathrm{v}$ nadaljnjem žlahtnjenju genotipov koruze $\mathrm{z}$ dobrimi kakovostnimi lastnostmi zrnja.

Ključne besede: lokalne populacije koruze, Kosovo, pridelek zrnja, beljakovine, olje, škrob

\footnotetext{
1 The University of Prishtina, Faculty of Agriculture, Kosovo, Asoc. Prof., e-mail: salialiu02@gmail.com

2 The University of Prishtina, Faculty of Agriculture, Kosovo, Asoc. Prof.

3 The University of Prishtina, Faculty of Agriculture, Kosovo, Prof.

4 The Faculty of Agriculture science and Food, Macedonia, Assistant Prof.
} 


\section{INTRODUCTION}

Maize (Zea mays L.) is considered to be a major source of food for livestock and humans due to its relatively high content of proteins, oil, starch and some other important vitamins such as vitamin B and B12. Yellow maize can provide a substantial amount of vitamin $A$, and the maize germ is rich in vitamin E (Okoruwa et al., 1996).

The maize crop is considered to be an integral part of Kosovo's agricultural production system and has a potential to compete with other crops. In order to have access to the global market, there is a need to improve the yield quality with judicious use of inputs (Saleem et al., 2008).

Maize is commonly used in animal feed as an energy source for its high starch content (Oliveira et al., 2006). Several million people, particularly in developing countries, derive their protein and calorie requirements from maize. Some of the most important traits of interest in the maize market are protein and oil content. The protein content (PC) is a quantitative trait and several studies have pointed out that there is a great number of genes involved in its control (Mittelman et al., 2003). Protein is an expensive but necessary constituent of both food and feed. Grain protein quantity in ordinary maize is relatively low $\left(80-110 \mathrm{~g} \mathrm{~kg}^{-1}\right)$ and of poor quality because of low levels of amino acids, lysine and tryptophan (Bjarnason and Vasal, 1992). Maize protein which ranges from 6 to $12 \%$ is regarded to be inferior because it is low in lysine and tryptophan (FAO, 1988). This may cause nutritional deficiencies when maize is used as an exclusive protein source, without the addition of supplements (Glover and Mertz, 1987). Some proteins in maize have anti-fungal qualities. The basis of resistance to fungal infection may lie with protein content, type, or distribution in the tissue (Guo et al., 1997).
The existence of genetic variability and the prospect of selection for protein content in maize have been demonstrated in several studies (Miću et al., 1995). Most of the oil is in the germ of the kernel. Oil and protein contents have been increased to levels almost twice as high as those of the original grain (Jugenheimer, 1961). High-oil corn (HOC) inbreds were first developed in 1896 and some hybrids containing $6-8 \%$ oil (Haumann, 1996), and affected by the size of embryo, maturity, and position of the kernel on the ear (Lambert 2001). Breeding studies in maize to enhance fatty acid composition started in 1970's; however, they have not continued. Research in this area dealt with different aspects of grain quality, focusing mainly on determination of the grain quality traits and characterization of maize genotypes in terms of fatty acid composition (Egesel et al., 2011).

The major use of HOC is in livestock feed because of its higher metabolizable energy value (Weber, 1987). The developing countries have more areas dedicated to maize cultivation than developed countries, but yield in the latter is about four times higher. While most production in developing countries is used for human consumption, in developed world, it is mainly used for animal feed and industry (FAO, 1988). As indicated earlier, maize has three possible uses such as food, feed for livestock and raw material for industry.

Maize is one of the most important grain crops in Kosovo, with over 60,000 hectares in production (MAFRD, 2010) where the area under local maize populations is more than $5 \%$. In most cases, the cultivation of local populations is associated with their adaptability to specific environments and with their nutritional value. It is frequently used for human consumption as corn bread that can be consumed together with milk. 
The main objective of the present study was to describe and analyze twenty local maize populations and to identify the quality traits with more differentiating ability.

\section{MATERIAL AND METHODS}

Plant material and experimental design: soil in the experimental area is classified as Twenty local maize populations (LMP), vertisol (black soil). Standard agronomic collected from different regions of Kosovo, practices were used to provide adequate were used in this study (Table 1). The nutrition and keep the plots disease free. Each experiment was carried out in a randomized complete block design with three replicates in Prishtina $42^{\circ} 38^{\prime} 29.76$ " N and $21^{\circ} 07^{\prime} 16.499^{\prime \prime} \mathrm{E}$ on $571 \mathrm{~m}$ of altitude in 2010 . The climate of the region is semiarid with hot summers. The plot consisted of a row $5 \mathrm{~m}$ long with an inter and intra row plant spacing of $0.75 \times 0.25 \mathrm{~m}$, resulting in a population density of 53,000 plants $\mathrm{ha}^{-1}$. Area of individual plots in each replication was $15 \mathrm{~m}^{2}$.

Table 1. Geographical data of collected Kosovo local maize populations

\begin{tabular}{|c|c|c|c|c|}
\hline Populations & Geographical origin & Longitude & Latitude & Elevation \\
\hline GBK-1 & Drenas & $020^{\circ} 44^{\prime} 43^{\prime \prime}$ & $42^{\circ} 41^{\prime} 50^{\prime \prime}$ & 567 \\
\hline GBK-2 & Malisheve & $020^{\circ} 44^{\prime} 09^{\prime \prime}$ & $42^{\circ} 28^{\prime} 12^{\prime \prime}$ & 562 \\
\hline GBK-3 & Malisheve & $020^{\circ} 43^{\prime} 22^{\prime \prime}$ & $42^{\circ} 27^{\prime} 56^{\prime \prime}$ & 576 \\
\hline GBK-4 & Drenas & $020^{\circ} 45^{\prime} 53^{\prime \prime}$ & $42^{\circ} 41^{\prime} 35^{\prime \prime}$ & 694 \\
\hline GBK-5 & Prishtine & $021^{\circ} 04^{\prime} 00^{\prime \prime}$ & $42^{\circ} 35^{\prime} 05^{\prime \prime}$ & 810 \\
\hline GBK-6 & Kamenice & $021^{\circ} 31^{\prime} 32^{\prime \prime}$ & $42^{\circ} 34^{\prime} 16^{\prime \prime}$ & 766 \\
\hline GBK-7 & Kamenice & $021^{\circ} 25^{\prime} 32^{\prime \prime}$ & $42^{\circ} 33^{\prime} 56^{\prime \prime}$ & 812 \\
\hline GBK-8 & Lipjan & $021^{\circ} 07^{\prime} 20^{\prime \prime}$ & $42^{\circ} 31^{\prime} 45^{\prime \prime}$ & 551 \\
\hline GBK-9 & Podujeve & $021^{\circ} 12^{\prime} 12^{\prime \prime}$ & $42^{\circ} 33^{\prime} 39^{\prime \prime}$ & 598 \\
\hline GBK-10 & Drenas & $020^{\circ} 54^{\prime} 06^{\prime \prime}$ & $42^{\circ} 34^{\prime} 50^{\prime \prime}$ & 585 \\
\hline GBK-11 & Vushtrri & $021^{\circ} 59^{\prime} 26^{\prime \prime}$ & $42^{\circ} 50^{\prime} 46^{\prime \prime}$ & 557 \\
\hline GBK-12 & Ferizaj & $021^{\circ} 09^{\prime} 39^{\prime \prime}$ & $42^{\circ} 22^{\prime} 15^{\prime \prime}$ & 580 \\
\hline GBK-13 & Suhareke & $020^{\circ} 49^{\prime} 02^{\prime \prime}$ & $42^{\circ} 21^{\prime} 45^{\prime \prime}$ & 388 \\
\hline GBK-14 & Vushtrri & $020^{\circ} 58^{\prime} 30^{\prime \prime}$ & $42^{\circ} 33^{\prime} 38^{\prime \prime}$ & 518 \\
\hline GBK-15 & Drenas & $020^{\circ} 42^{\prime} 32^{\prime \prime}$ & $42^{\circ} 39^{\prime} 21^{\prime \prime}$ & 586 \\
\hline GBK-16 & Drenas & $020^{\circ} 42^{\prime} 46^{\prime \prime}$ & $42^{\circ} 39^{\prime} 30^{\prime \prime}$ & 565 \\
\hline GBK-17 & Skenderaj & $020^{\circ} 48^{\prime} 23^{\prime \prime}$ & $42^{\circ} 45^{\prime} 00^{\prime \prime}$ & 623 \\
\hline GBK-18 & Skenderaj & $020^{\circ} 47^{\prime} 39^{\prime \prime}$ & $42^{\circ} 44^{\prime} 39^{\prime \prime}$ & 597 \\
\hline GBK-19 & Skenderaj & $020^{\circ} 48^{\prime} 04^{\prime \prime}$ & $42^{\circ} 44^{\prime} 39^{\prime \prime}$ & 603 \\
\hline GBK-20 & Shtime & $020^{\circ} 07^{\prime} 06^{\prime \prime}$ & $42^{\circ} 44^{\prime} 40^{\prime \prime}$ & 610 \\
\hline
\end{tabular}

Laboratory studies: At harvest time, five random ears were selected from each plot, resulting in a total of 15 ears per individual population. Grains were carefully removed by hand. From each population, an equal number of grains was taken from each plot, mixed together in order to form a balanced sample and then subjected to analyses in the laboratory. The grains obtained were grounded to form a fine powder. The chemical analyses included protein content (PC), starch content (SC) and oil content (OC). Analyses were based on standard methods: PC was determined by the Kjeldahl, while OC was 
determined by extraction using Soxhlet method (using petroleum ether at boiling point $40-60{ }^{\circ} \mathrm{C}$ ). Ash content of each sample was determined by drying samples at $550{ }^{\circ} \mathrm{C}$.

Statistical analyses: All statistical analyses were performed with the SPSS software (version 15.0, SPSS Inc., 2006). Mean values and variation coefficients were used in the statistical analyses. Effects of the studied traits were evaluated by ANOVA. In order to asses the differentiation of local maize populations (LMP's) based on all variables that were measured, the Canonical Discriminant Analyses (CDA) was applied. CDA is a technique for classifying a set of observation into predefined classes. Relationship among different variables of the quality analyses were tested by Pearson's correlation test.

\section{RESULTS AND DISCUSSION}

Significant differences among the LMP's for grain yield and grain quality such as content of oil, protein, starch, ash and moisture were determined (Table. 2).

Table 2: Mean squares for grain yield and quality parameters of 20 Kosovo local maize populations

\begin{tabular}{|c|c|c|c|c|c|c|c|c|c|c|c|c|c|}
\hline $\begin{array}{c}\text { Sources of } \\
\text { variation }\end{array}$ & d.f. & $\begin{array}{l}\text { Yield } \\
\text { per } \\
\text { plant } \\
(\mathrm{g})\end{array}$ & & $\begin{array}{c}\text { Oil } \\
\text { Content } \\
(\%)\end{array}$ & & $\begin{array}{l}\text { Protein } \\
\text { Content } \\
(\%)\end{array}$ & & $\begin{array}{l}\text { Starch } \\
\text { Content } \\
(\%)\end{array}$ & & $\begin{array}{c}\text { Ash } \\
\text { Content } \\
(\%)\end{array}$ & & $\begin{array}{l}\text { Moisture } \\
\text { Content } \\
(\%)\end{array}$ & \\
\hline LMP's & 19 & 2.895 & $* *$ & 2.863 & $* *$ & 18.593 & $* *$ & 4.584 & $* *$ & 2.863 & $* *$ & 247.49 & $* *$ \\
\hline CV\% & & 18.26 & & 13.37 & & 4.40 & & 1.49 & & 3.10 & & 3.62 & \\
\hline Error & 38 & 217.46 & & 0.0019 & & 0.0437 & & 0.728 & & 0.0019 & & 0.003 & \\
\hline
\end{tabular}

** Significant at $p=0.01$.

The analysis of variance (ANOVA) showed that the LMP's differed in most characteristics (Table 3). Mean values of all measured characteristics are presented in Table 3. The mean values of the grain yield per plant at LMP's were $79.33 \mathrm{~g}$ plant $^{-1}$. It is evident from our results that local maize population GBK-7 had maximum grain yield per plant $(105.13 \mathrm{~g}$ plant $^{-1}$ ) which is $25.8 \mathrm{~g}_{\text {plant }}{ }^{-1}$ or $32.52 \%$ higher than the mean values, whereas LMP's for GBK-13 had the lowest grain yield (59.62 $\mathrm{g}_{\text {plant }}^{-1}$ ) which is $19.71 \mathrm{~g} \mathrm{plant}^{-1}$ or $24.84 \%$ lower than the mean value $\left(79.33 \mathrm{~g} \mathrm{plant}^{-1}\right)$. High oil content maize is a special type that has been bred to have higher percent oil content (OC) than regular yellow maize. Typically, oil content of yellow maize varies from 3.5 to $4 \%$. Ideally, high oil content maize should contain from 7 to $8 \%$ of oil (Heiniger, 1997). Kernel oil content is considered to be a quantitative trait controlled by numerous genes with small effects (Dudley, 1977). The data showed a relatively wide range among the LMP's for OC. The overall mean value for the OC was $4.44 \%$. The genotype GBK-5 exhibited maximum $\mathrm{OC}$ value with $5.57 \%$, while GBK-13 had the lowest OC value $(2.56 \%)$. Different range of variation (5.26 and $7.17 \%$ ) was observed by Berardo et al., (2009). Has et al., (2009) reported different values which varied from 0.04 to $12.3 \%$. Significant values of OC were also reported by Saleem et al. (2008). 
Table 3: Mean values of grain yield and quality characters in Kosovo local maize populations

\begin{tabular}{|c|c|c|c|c|c|c|}
\hline $\begin{array}{l}\text { Local maize } \\
\text { populations }\end{array}$ & $\begin{array}{c}\text { Ash content } \\
(\%)\end{array}$ & $\begin{array}{c}\text { Oil content } \\
(\%)\end{array}$ & $\begin{array}{c}\text { Moisture } \\
\text { content } \\
(\%)\end{array}$ & $\begin{array}{c}\text { Protein } \\
\text { content } \\
(\%)\end{array}$ & $\begin{array}{c}\text { Starch } \\
\text { content } \\
(\%)\end{array}$ & $\begin{array}{c}\text { Yield } \\
\left.\text { (plant }^{-1} \mathrm{~g}\right)\end{array}$ \\
\hline GBK-1 & $1.44 \pm 0.020$ & $4.37 \pm 0.032$ & $14.48 \pm 0.030$ & $13.02 \pm 0.215$ & $68.58 \pm 0.535$ & $69.69 \pm 1.060$ \\
\hline GBK-2 & $1.38 \pm 0.028$ & $4.53 \pm 0.316$ & $14.14 \pm 0.040$ & $11.69 \pm 0.049$ & $69.87 \pm 0.640$ & $88.97 \pm 9.763$ \\
\hline GBK-3 & $1.33 \pm 0.080$ & $3.83 \pm 0.520$ & $14.56 \pm 0.005$ & $12.50 \pm 0.205$ & $70.70 \pm 0.362$ & $102.55 \pm 7.230$ \\
\hline GBK-4 & $1.38 \pm 0.025$ & $4.01 \pm 0.198$ & $14.84 \pm 0.085$ & $11.75 \pm 0.280$ & $70.96 \pm 0.753$ & $93.30 \pm 5.863$ \\
\hline GBK-5 & $1.39 \pm 0.055$ & $5.57 \pm 0.456$ & $14.16 \pm 0.045$ & $11.59 \pm 0.176$ & $69.97 \pm 0.761$ & $86.29 \pm 14.657$ \\
\hline GBK-6 & $1.34 \pm 0.051$ & $4.30 \pm 0.445$ & $14.85 \pm 0.020$ & $11.72 \pm 0.200$ & $70.19 \pm 0.223$ & $82.08 \pm 21.328$ \\
\hline GBK-7 & $1.34 \pm 0.035$ & $4.78 \pm 0.413$ & $14.14 \pm 0.040$ & $11.32 \pm 0.202$ & $70.43 \pm 0.355$ & $105.13 \pm 11.017$ \\
\hline GBK-8 & $1.28 \pm 0.045$ & $4.31 \pm 0.518$ & $14.50 \pm 0.078$ & $11.05 \pm 0.435$ & $72.15 \pm 1.162$ & $82.43 \pm 4.787$ \\
\hline GBK-9 & $1.35 \pm 0.015$ & $4.49 \pm 0.181$ & $14.67 \pm 0.075$ & $11.02 \pm 0.258$ & $70.02 \pm 0.920$ & $99.86 \pm 8.741$ \\
\hline GBK-10 & $1.35 \pm 0.032$ & $4.27 \pm 0.208$ & $14.45 \pm 0.005$ & $11.64 \pm 0.081$ & $70.23 \pm 0.309$ & $78.34 \pm 17.001$ \\
\hline GBK-11 & $1.34 \pm 0.043$ & $4.37 \pm 0.457$ & $14.56 \pm 0.046$ & $11.59 \pm 0.134$ & $70.92 \pm 0.453$ & $69.83 \pm 17.969$ \\
\hline GBK-12 & $1.31 \pm 0.052$ & $4.40 \pm 0.705$ & $14.07 \pm 0.015$ & $11.15 \pm 0.223$ & $70.68 \pm 0.850$ & $75.77 \pm 17.339$ \\
\hline GBK-13 & $1.36 \pm 0.030$ & $2.56 \pm 0.181$ & $16.42 \pm 0.111$ & $11.99 \pm 0.161$ & $70.36 \pm 0.420$ & $59.62 \pm 16.243$ \\
\hline GBK-14 & $1.36 \pm 0.023$ & $4.66 \pm 0.408$ & $14.61 \pm 0.077$ & $11.92 \pm 0.217$ & $70.34 \pm 1.125$ & $78.43 \pm 3.458$ \\
\hline GBK-15 & $1.45 \pm 0.070$ & $4.44 \pm 0.866$ & $14.19 \pm 0.043$ & $12.49 \pm 0.308$ & $68.63 \pm 1.341$ & $85.47 \pm 16.479$ \\
\hline GBK-16 & $1.43 \pm 0.032$ & $4.89 \pm 0.394$ & $14.24 \pm 0.062$ & $12.52 \pm 0.070$ & $67.39 \pm 0.747$ & $67.36 \pm 29.061$ \\
\hline GBK-17 & $1.38 \pm 0.026$ & $4.67 \pm 0.050$ & $14.01 \pm 0.075$ & $11.86 \pm 0.160$ & $69.41 \pm 0.660$ & $72.67 \pm 15.445$ \\
\hline GBK-18 & $1.36 \pm 0.060$ & $5.25 \pm 0.728$ & $14.10 \pm 0.010$ & $11.67 \pm 0.081$ & $69.33 \pm 1.236$ & $67.21 \pm 14.839$ \\
\hline GBK-19 & $1.37 \pm 0.023$ & $4.85 \pm 0.496$ & $14.63 \pm 0.026$ & $12.11 \pm 0.209$ & $69.24 \pm 1.400$ & $74.39 \pm 18.798$ \\
\hline GBK-20 & $1.41 \pm 0.047$ & $4.34 \pm 0.699$ & $14.18 \pm 0.095$ & $11.60 \pm 0.081$ & $70.40 \pm 1.013$ & $47.33 \pm 10.565$ \\
\hline Mean & 1.36 & 4.44 & 14.48 & 11.81 & 69.90 & 79.33 \\
\hline $\mathrm{CV} \%$ & 3.10 & 13.37 & 3.62 & 4.40 & 1.49 & 18.26 \\
\hline
\end{tabular}

The variation for protein content (PC) was found to be higher than the variation for OC. The ANOVA indicated that the differences among the LPM's for PC were highly significant (Table 3). The mean value of PC observed in the present study was $11.81 \%$. Some of LMP's were identified with high grain $\mathrm{PC}$ ranging from 11.02 to $13.02 \%$. This can be regarded as a relatively high level of PC. The LMP's also showed a high genetic variation $(16.93 \%)$. The variation for the protein content has been well demonstrated by numerous studies. Has et al., (2009) at some LMP's reported variation from 11.2 to $15.6 \%$; while Prasanna et al., (2001) presented different results which varied from 8.9 to $10.2 \%$. From the data shown in Table 3 it is evident that the starch content (SC) of maize kernels depends to a very large extent on genotype of population. The starch content (SC) ranging between 67.39 and $72.15 \%$, while the grand mean values of $\mathrm{SC}$ was $69.90 \%$. There were significant differences at $p=0.01$. Similar results $(58.1$ to $72 \%)$ for SC in different LMP were reported by Has et al., (2009). Also ash content (AC) ranged from 1.28 to $1.45 \%$. 
Table 4: Summary statistics for canonical discriminant standardized functions

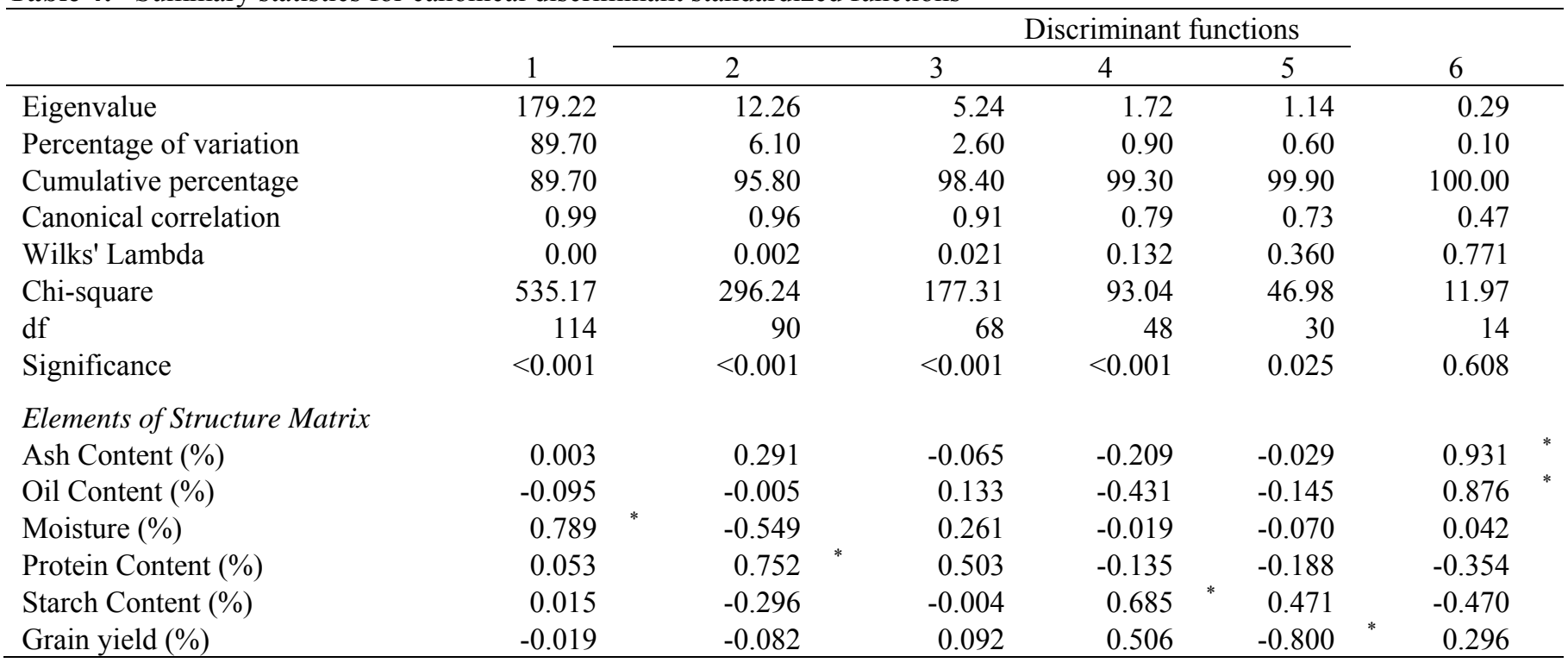

* Largest absolute correlation between each variable and any discriminant function

In table 4 the canonical discriminant functions are described, the eigenvalue, percentages of variation of each function and the cumulative variance of the six discriminant functions. Table presents as well the standardized elements of structure matrix. The first two canonical discriminant functions were significant at $p<0.01$. It is important to point out the great relevance of the first two discriminant functions justifying $95.80 \%$ of the variability. The first discriminant function showed a significant positive correlation with the moisture $(0.789)$ following by protein and starch content $(0.053$ and 0.015$)$. But, the negative correlation (-0.019) was determined between first descriminant function and grain yiled (Table 5).

Table 5: Pearson's correlations between yield and grain quality traits

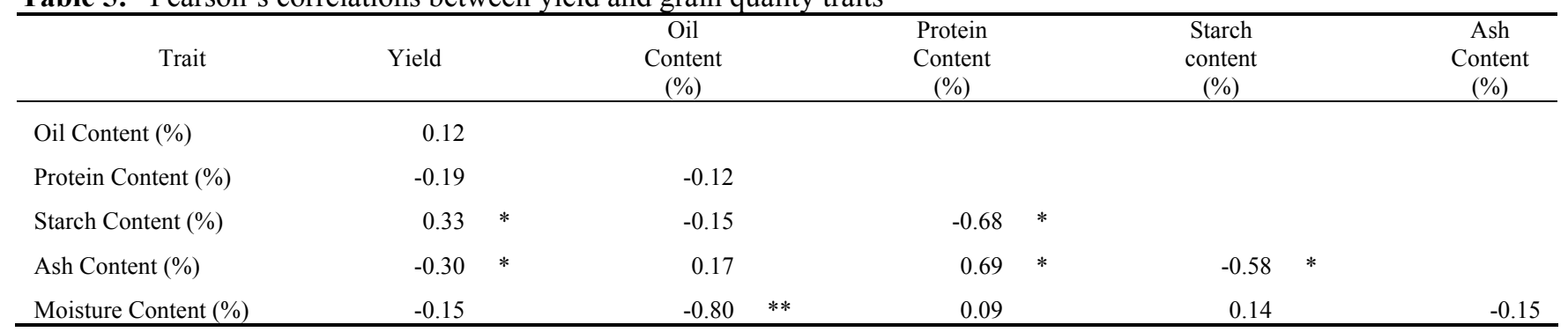

$* \quad=$ significant at $p=0.05$. and $p=0.01$

Maize breeders expect that kernel protein and oil content should be negatively correlated with plant yield. In our study, grain yield per plant was positively and significantly correlated with starch content $\left(r=0.33^{*}\right)$, positively and nonsignificantly correlated with oil content $(r=0.12)$ and was negatively correlated with protein content $(r=-0.19)$.

Also, the significant correlation was obtained between Ash content (AC) and protein content (PC) on value 0.69 . Table 5. The possible cause for observed correlation was probably due to reduction of starch content in the grains. 
The presented results are in partial agreement

et al., (2008).

with the results of Has et al., (2009) and Salem

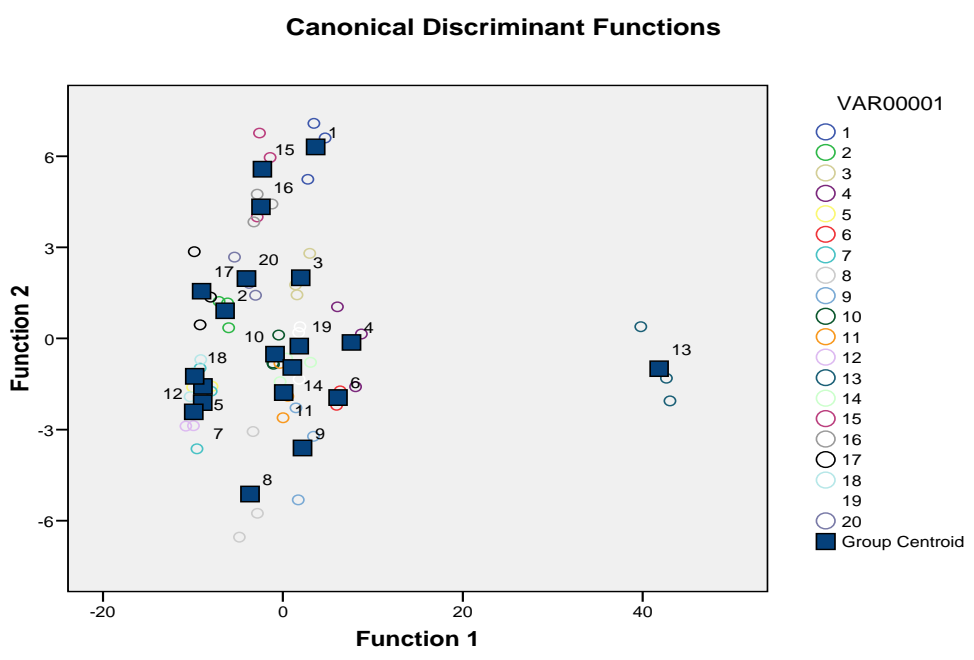

Figure 1: Canonical discriminant analyses of local maize populations by grain yield and quality characteristics applied (4 - 7 mismatches allowed at the 3' end of primers).

The canonical discriminant analysis of the traits is presented in Figure 1. The first canonical functions described $89.7 \%$ and a second canonical function is $6.1 \%$ of the existing variance. Ash content had the strongest influence in the Function 1, while the Functions 2 was mostly influenced by the oil content followed by protein content and starch content.

\section{CONCLUSIONS}

The study showed that there was a significant genetic variability for many traits among local maize populations. High variability was determined for PC, OC and SC. Positive and significant correlations were found between yield and starch contents. Negative correlation was found between yield and protein content. The first canonical function described $89.7 \%$ and a second canonical function is $6.1 \%$ of the existing variance. The investigated maize populations could be considered as a source of new genetic variability, and could be successfully used for the development of maize inbred lines in the Kosovo breeding program. The evaluation of plant genetic resources has been considered of prime importance, especially in those species having economic importance.

\section{ACKNOWLEDGEMENTS}

The first author gratefully acknowledges the National Gene Bank of Kosovo for providing maize plant material which was included in this study. 


\section{REFERENCES}

Berardo, N., Mazzineli, G., Valoti, P., Lagana, R., Redaelli, R. 2009. Characterization of maize germplasm for the chemical composition of the grain. J. Agr. Food Chem., 57: 2378-2384.

Bjarnason, M., Vasal, K. 1992. Breeding quality protein maize (QPM). Plant Breeding Reviews, 9: 181-216.

Dudley, J. 1977. Seventy-six generations of selection for oil and protein percentage in maize. Book of Proceedings of the International Conference on Quantitative Genetics. ISU, 459-473.

Egesel,O.C., Kahriman F., Gul M. 2011. Discrimination of maize inbreeds for kernel quality traits and fatty acid composition by a multivariate technique. Acta scientarium Agronomy;33:11031 pp.

FAO. 1988. Food and Agriculture Organization. www.fao.org/docrop

Glover, D., Mertz, T. 1987. Nutritional quality of cereal grains. Agronomy Monograph, 28: 183-336.

Guo, B., Chen, Z., Brown, R., Lax, A., Cleveland, E., Russin, D. 1997. Germination induces accumulation of specific proteins and antifungal activities in corn kernels. Phytopathology, 87: 1174-1178.

Has, V., Has, I., Pamfli, D., Copandean, A., Campean, S. 2009. Evaluation of turda maize gerplasm for phenotypic variability in grain chemical composition. Maydica, 54: 313-320.

Haumann, B. 1996. Corn research looks at changing oil content. Inform, 7: 576-583.

Heiniger, R., Dunphy, J. 1997. High oil corn production q\&a. NC State University, 22-28.

Jugenheimer, R.W. 1961. Breeding for oil and protein content in maize. Euphytica, 10: 152-156.
Lambert ,R.J. 2001. High-oil corn hybrids In; Speciality corns. Hallauer A.R. Ed., second edition. CRC Press,Boca Raton,FL., USA. 131-154 pp.

MAFRD. 2010. Ministry of Agriculture, Forestry, Rural Development of Kosovo, Statistics Division. Database for Sum of temperatures and rainfall.

Miću, V., Partas, V., Rotari, I. 1995. The revealing and selection of high protein sources of maize. Maize Genetic Cooperation Newsletter. 69: 115.

MINITAB-14. 2008. www.minitab.com/contacts.

Mittelman, A., Filho, J., Lima, G., Klain, C., Tanaka, R. 2003. Potential of the esa23b maize population for protein and oil content improvement. Sci. Agricola, 60: (2), 319-327.

Okoruwa, V.O., Jabbar, M.A., Akinwumi, J.A.1996. Crop-livestock competition in the West African Derived Savannah: Application of a Multiobjective Programming Model. Agricultural Systems 52: (4), 439-452.

Oliveria, J., Chaves, L., Duarte, J., Ribeiro, K., Brasil, E. 2006. Heterosis for oil content in maize populations and hybrids of high quality protein. Crop Breed and Apl. Biotechnol. 6: 113-120.

Prasanna, M., Vasal, K., Kassahun, B., Singh, N. 2001. Quality protein maize. Current Science, 81: (10), 1308-1319.

Saleem, M., Ahsan, M., Salam, M., Majeed, A. 2008. Comparative evaluation and correlation estimates for grain yield and quality attributes in maize. Pak. J. Bot. 40: (6), 2361-2367.

SPSS-16. 2006. Statistical package programme.

Weber, E. 1987. Lipids of the kernel in corn. Chemistry and Technology, 311-349. 